\section{Sweetpotato Clone Tolerance to Weed Interference}

\author{
Don R. La Bonte ${ }^{1}$ \\ Department of Horticulture, Louisiana State University Agricultural Center, \\ Louisiana Agricultural Experiment Station, Baton Rouge, LA 70803-2120
}

Howard F. Harrison

U.S. Department of Agriculture, Agricultural Research Service, United States Vegetable Laboratory, Charleston, SC 29414

Carl E. Motsenbocker

Department of Horticulture, Louisiana State University Agricultural Center, Louisiana Agricultural Experiment Station, Baton Rouge, LA 70803-2120

Additional index words. Ipomoea batatas, breeding, crop interference, crop tolerance, integrated pest management, light interception

\begin{abstract}
Field experiments were conducted to assess how sweetpotato [Ipomoea batatas (L.) Lam.] clones interfere with weeds and how clones tolerate weed interference. Eleven clones with architecturally different canopies were evaluated for yield, canopy surface area and dry mass, weed dry mass, and light interception at ground level. A 2 -fold difference in ground area covered by canopy surface area was observed among the eleven clones 42 days after planting, and a 3-fold difference in canopy dry mass at harvest. Yields were reduced from $14 \%$ to $68 \%$ by weed interference. The yields of high-yielding clones, 'Beauregard', 'Excel', L87-125, 'Regal', 'Centennial', and W-274, were reduced to a significantly greater extent by weeds than were yields of the other five clones. No differences were observed between clones for weed suppression as measured by weed dry mass at harvest and ground light interception. Short-internode and long-internode clones had similar competitive abilities. Yield of high-yielding clones was impacted more by weed interference than was that of low-yielding clones.
\end{abstract}

High yields of sweetpotato [Ipomoea batatas (L.) Lam.] in the tropics and subtropics are dependent on adequate weed control. Yield losses of up to $90 \%$ occur in the tropics if weeding is delayed during the initial slow growth period (Akobundu, 1980). Yield losses in subtropical production regions of the United States range from $40 \%$ to $76 \%$ for weedy controls in herbicide trials (Porter, 1990). A number of herbicides control a broad spectrum of weeds in sweetpotato (AmpongNyarko, 1994) but lack of registration limits their use in the United States. Clomazone $\{2-$ [(2-chlorophenyl) methyl]-4,4-dimethyl-3isoxazolidone $\}$ is the only broad-spectrum,

\footnotetext{
Received for publication 14 May 1998 Accepted for publication 12 Aug. 1998. Approved for publication by the Director of the Louisiana Agricultural Experiment Station as manuscript number 96-28-0069. The research was supported by funds from the Louisiana Sweet Potato Advertising and Development Commission, and by state and matching funds allocated to the Louisiana State University Agricultural Center. The authors appreciate the technical assistance of D. Romaine, and K. Stetina, and the assistance of M.I. Buteler with statistical analysis. The cost of publishing this paper was defrayed in part by the payment of page charges. Under postal regulations, this paper therefore must be hereby marked advertisement solely to indicate this fact. ${ }^{1}$ To whom reprint requests should be addressed. Email address: dlabonte@agctr.lsu.edu
}

preemergence herbicide currently registered throughout the United States. Clomazone does not effectively control several important weed species, including Cyperus esculentus L., Mollugo verticillata L., and Amaranthus sp. (Porter, 1995). Growers report inadequate weed control when clomazone is not activated or when clomazone-tolerant weeds are present (M.J. Cannon, Louisiana State Univ. Agr. Center, personal communication).

Given the few registered herbicides available, sustaining high sweetpotato yields in the United States will increasingly require integrated pest management (IPM) approaches to weed control. An integral component of any sweetpotato IPM strategy is using a clone that can sustain its yield potential in the presence of weeds and/or suppress weed growth. Breeders, however, seldom select for competitiveness (Callaway, 1992), and weeds are unique among the major crop pests in this respect (Akobundu, 1990). Reports evaluating sweetpotato competitive ability with weeds are few. Levett (1992) found differences in yield and storage root number in two sweetpotato clones subjected to various hand-weeding regimes in Papua New Guinea. Weed suppressing clonal characteristics in sweetpotato are not listed in Food and Agriculture Organization weed management guidelines (Ampong-Nyarko, 1994), whereas these characteristics are described for other crops. Such characteristics, if found, could be intentionally selected for in sweetpotato breeding programs.
Varietal response to weeds has been reviewed by Callaway (1992). Competition studies in corn (Zea mays L.) (Ford and Mt. Pleasant, 1994), cotton (Gossypium hirsutum L.) (Chandler and Meredith, 1983), potato (Solanum tuberosum L.) (Sweet et al., 1974), and soybeans [Glycine $\max (\mathrm{L}$.$) Merr.]$ (Burnside, 1972; McWhorter and Hartwig, 1972; Newcomer et al., 1986) indicated that some varieties possess superior weed-suppressing qualities and/or higher productivity when in competition with weeds. For instance, a dense, light-intercepting plant cover reportedly controlled weeds in Irish potato (Sweet et al., 1974). Early-maturing cotton varieties were less competitive on a yield basis than latematuring varieties when grown with spurred anoda [Anoda cristata (L.) Schlecht] (Chandler and Meredith, 1983). In soybean, better weed suppression was attributed to an indeterminate growth habit and faster canopy development (Newcomer et al., 1986). In corn, no plant parameter was directly implicated as effective in suppressing weeds, even though some hybrids were more productive under high weed pressures (Ford and Mt. Pleasant, 1994).

Our objectives were to investigate whether 11 sweetpotato clones with different canopy architectures differed in weed tolerance as measured by yield, and to identify plant canopy characteristics that increase sweetpotato's competitiveness against weeds.

\section{Materials and Methods}

Field experiments were conducted at the Dept. of Horticulture Hill Farm, Baton Rouge, La., in 1992, at the Burden Research Station, Baton Rouge, La., in 1994, 1995, and 1997, and at the U.S. Vegetable Laboratory Farm, Charleston, S.C., in 1992 and 1994. Soils at the 1992 Louisiana site were a Loring silt loam (Typic Fragiudalf) with $<1 \%$ organic matter and $\mathrm{pH}$ 6.0. The soils at the other Louisiana site were an Olivier silt loam (Aquic Fragiudalf) with $<1 \%$ organic matter and $\mathrm{pH} 6.5$. Soils at the South Carolina site were a Yonges Loamy sand (Aeric Paleaquults) with $<1 \%$ organic matter and $\mathrm{pH} 6.3$ to 6.8 .

The experimental design was a randomized complete block with a split-plot arrangement of treatments in three or four replications. Clones composed the main plot, and included upright, short-internode bunch (compact) clones (W-241, W-279, and L87-125), and medium- (PI-273496) to long-internode, trailing (spreading) vine clones ('Beauregard', 'Carolina Nugget', 'Centennial', 'Excel', 'Jewel', and 'Regal'). Leaf types also varied and included deeply lobed (palmate) leaf clones ('Carolina Nugget', PI-273496, and L87-125) and entire-leaf clones ('Beauregard', 'Centennial', 'Excel', 'Jewel', W-274, W-279, and 'Regal'). Palmate sweetpotato leaves shade more than do entire leaves (less overlapping). Clones W-279 and PI-273496 were not used at the South Carolina location. These clones represent a broad spectrum of canopy architectures found in sweetpotato (Huaman, 1987). Weed control treatments composed the sub- 
plots and consisted of either no weed control (weedy) or hand-weeding (weed-free) up to 42 $\mathrm{d}$ after planting (DAP). Subsequent weekly hand weeding was not necessary because the canopies quickly covered the soil surface and precluded further weed growth above the canopy.

The main plots consisted of six rows, $6.0 \mathrm{~m}$ long and $1.2 \mathrm{~m}$ (1.1 m in South Carolina) between rows, with each row containing 20 plants spaced $0.3 \mathrm{~m}$ apart. All growth measurements were taken from the center row of the weedy and weed-free treatments. The following measurements were taken from a $1-\mathrm{m}^{2}$ quadrat of this row: 1) sweetpotato canopy surface area at 42 DAP (weed-free plots only); 2) weed dry mass at harvest $\left(70^{\circ} \mathrm{C}\right.$ for $48 \mathrm{~h}$ ) (weedy plots only); and 3) sweetpotato canopy dry mass at harvest $\left(70^{\circ} \mathrm{C}\right.$ for $\left.48 \mathrm{~h}\right)$. The center row of each subplot was harvested for total root yield. Sweetpotato canopy surface area, as a percentage of the total ground surface area, was estimated by an overhead black and white photograph of the quadrat placed equidistant over the row top for each weed-free plot. White cardboard was placed under the canopy to enhance the contrast. The photographs were scanned by a leaf area meter (Area Meter RS232C; Delta T Devices, Cambridge, England) once to determine total area and again to measure total leaf area.

In 1995 and 1997, a study was established at Baton Rouge to determine light interception by sweetpotato canopies. The experimental design was a completely randomized design with three replications. Each experimental unit consisted of three rows, each containing 20 plants, spaced as before. The center row of each plot was assessed 42 DAP for ground level light interception according to Board and Tan (1995), using a 1.0-m-long light sensor (LI-COR Line Quantum sensor; LI-COR, Lincoln, Nebr.) placed parallel to plant rows at ground level and at 0-, 15-, and 30-cm intervals from stem bases.

Commercial sweetpotato cultural practices as recommended by the Louisiana Cooperative Extension Service (Boudreaux, 1994) or previously described (Harrison and Peterson, 1991) in South Carolina were followed, with the exception of weed control. All experiments were established in late May or early June and harvested at maturity 110 to 120 DAP. All plots, including the weedy subplots, were cultivated, using a two-row cultivator no more than twice up to 21 DAP and before rapid vine elongation. Weed species varied by location; C. esculentus and Digitaria sanquinalis (L.) Scop. were predominant at Baton Rouge, while Eleusine indica (L.) Gaertn, Panicum texanum Bucki., C. esculentus, and Amaranthus sp. were the dominant weeds at Charleston.

The analysis of variance (ANOVA) assumptions of normality and variance homogeneity were checked using stem and leaf plots, normal probability plots, and residuals vs. predicted values plots after adjusting the model (Proc univariate and Proc plot, SAS Institute, 1987). The canopy surface area data were arcsin-transformed prior to analysis. Tukey's Studentized range (HSD) test was used to statis- tically separate clones by canopy architecture, weed dry mass, and canopy surface area. The ANOVA analysis for yield showed a significant clone $\times$ weed treatment interaction $(P \leq$ 0.05 ). Thus, contrasts between least squares treatment means within each clone were performed, and the Bonferroni's test was used to obtain the overall family of comparisons probability value. Least significant difference (LSD) comparisons were calculated for percent light interception and for yield. Partial correlation coefficients were determined for: a) weed dry mass and yield in weedy treatments; b) percent yield reduction and weed dry mass; c) percent sweetpotato canopy surface area at 42 DAP and weed dry mass; and d) percent sweetpotato canopy dry-mass reduction and weed dry mass. All 'percentage reduction' variables refer to the percentage difference in a character in weedy vs. weed-free treatments, i.e., [(weedfree)-weedy]/weed-free. We used $P \leq 0.05$ as our test of significance in all analyses presented.

\section{Results}

Sweetpotato canopy dry mass. The weedy treatment significantly lowered vine mass by $53 \%$, pooled across all clones. This is consistent with Levett's (1992) results. No significant clone $\times$ weed treatment interaction or location $\times$ year interactions were observed for this character. The canopy dry-mass data were therefore pooled across weed treatments, locations, and years (Table 1). The highest ranking clone had a canopy dry mass $69 \%$ greater than that of the lowest ranking clone. Clones W-279 and 'Regal' produced the greatest canopy dry mass, which differed significantly from that of the lowest ranking clone, 'Carolina Nugget'. The canopy dry mass of all other clones did not differ significantly from those of W-279 and 'Regal'.

Canopy surface area at 42 DAP. Sweetpotato canopy surface area occupying a $1-\mathrm{m}^{2}$ quadrat ranged from $37 \%$ for 'Excel' to $81 \%$ for PI-273496 in weed-free treatments (Table 1). The percent canopy surface area of PI273496 was higher than that of all other clones except for 'Carolina Nugget', 'Jewel', and L87-125. No clear trends in canopy surface area were observed based on plant architecture. Bunch types W-279 and W-241 ranked lower in canopy surface area than most of the other clones, whereas the bunch type 87-125 ranked higher. None of the bunch clones differed significantly from trailing vine type clones. Similarly, of the clones with the highest surface area, two are deeply lobed leaf types and two are entire (round) leaf types.

Weed dry mass. Weed dry mass at harvest in weedy treatments ranged from $544 \mathrm{~g} \cdot \mathrm{m}^{-2}$ for 'Carolina Nugget' to $194 \mathrm{~g} \cdot \mathrm{m}^{-2}$ for W-241 (data not shown). There were no significant differences in weed dry mass among clones. No comparative published data are known for weed dry weights in sweetpotato; however, by inference, weed dry mass differed by $35 \%$ (nonsignificant at $P \leq 0.05$ ) for two Irish potato clones (Nelson and Giles, 1989).

Yield. Clone W-241 was the least affected by weed interference, with a $14 \%$ yield reduction. This clone also ranked highest among all clones for yields in weedy treatment (Fig. 1). In six of the 11 clones ('Beauregard', 'Excel', 'Centennial', L87-125, 'Regal', and W-274), yields were reduced significantly due to weed pressure, compared to the other clones in the study (Fig. 1). Reductions varied from $55 \%$ to $68 \%$. Except for L87-125 and 'Centennial', these clones ranked highest in yield among the 11 clones, and six, as a group, had significantly higher yield $(31 \%)$ than did the other five clones, in weed-free treatments. No significant difference in yield was observed in a weedy treatment group comparison.

Partial correlation coefficients. The partial correlation coefficient for weed dry mass vs. yield in weedy treatments was -0.48 ; that for percent yield reduction vs. weed dry mass was +0.48 . Partial correlation coefficients were nonsignificant for weed dry mass vs. percent sweetpotato canopy surface area at 42 DAP, and weed dry mass vs. percent sweetpotato canopy dry-mass reduction.

Ground light interception. In general, percent ground light interception decreased with increasing distance from the plant base, but did not differ significantly among clones in either years. Values ranged from $77 \%$ to $88 \%$ at $0 \mathrm{~cm}, 60 \%$ to $85 \%$ at $15 \mathrm{~cm}$, and $55 \%$ to $78 \%$ at $30 \mathrm{~cm}$ from the base of the plants $(1995$ data).

\section{Discussion}

No individual or group of clones, e.g., bunch vs. trailing vine clones, possessed a superior plant canopy (architecture) for suppressing weeds, based solely on weed dry mass. Likewise, partial correlation analysis suggests that sweetpotato canopy surface area coverage at 42 DAP was not important for weed dry-mass suppression nor was percentage sweetpotato canopy dry-mass reduction important for weedy and weed-free treatments. The relationship between these two canopy variables and weed dry mass may have little practical significance, since there was $100 \%$ canopy coverage in all clones well before harvest. Light penetration, a seemingly important character, was similar among the clones and may account for the consistency in clonal weed populations, given the wide range of canopy area coverage at 42 DAP exhibited by the clones. Our data do suggest that weed dry mass impacts yield. A positive partial correlation coefficient for weed dry mass and percent yield reduction suggests that an increase in weed interference (weed dry mass) is associated with an increased differential (\% reduction basis) in yield.

One possible criticism of our analyses of weed dry mass is that it is inclusive and therefore does not consider the many individual weed species present. For instance, 'Regal' has allelopathic properties against $C$. esculentus and is capable of reducing biomass of this weed species by $90 \%$ in field experiments (Harrison and Peterson, 1991). 'Regal', however, was no more effective than other clones in controlling the broad range of weed species 
Table 1 . Sweetpotato canopy dry mass $120 \mathrm{~d}$ after planting, and surface area $42 \mathrm{~d}$ after transplanting, averaged over years and locations.

\begin{tabular}{lcc}
\hline \hline & $\begin{array}{c}\text { Canopy dry } \\
\text { mass } \\
\left(\mathrm{g} \cdot \mathrm{m}^{-2}\right)\end{array}$ & $\begin{array}{c}\text { Canopy } \\
\text { surface }\end{array}$ \\
Clone & $423 \mathrm{area}^{\mathrm{z}}$ & $(\%)$ \\
\hline W-279 & $337 \mathrm{a}$ & $48 \mathrm{bc}$ \\
Regal & $320 \mathrm{ab}$ & $54 \mathrm{bc}$ \\
Jewel & $313 \mathrm{ab}$ & $56 \mathrm{abc}$ \\
W-274 & $290 \mathrm{ab}$ & $48 \mathrm{bc}$ \\
W-241 & $288 \mathrm{ab}$ & $44 \mathrm{bc}$ \\
Excel & $249 \mathrm{ab}$ & $37 \mathrm{c}$ \\
PI-273496 & $249 \mathrm{ab}$ & $81 \mathrm{a}$ \\
L87-125 & $246 \mathrm{ab}$ & $55 \mathrm{abc}$ \\
Beauregard & $232 \mathrm{ab}$ & $54 \mathrm{bc}$ \\
Centennial & $132 \mathrm{~b}$ & $54 \mathrm{bc}$ \\
Carolina Nugget & $67 \mathrm{ab}$ \\
\hline
\end{tabular}

${ }^{2}$ Based on a $1-\mathrm{m}^{2}$ quadrat figure centered on the row.

'Mean separation within columns by Tukey's Studentized range test, $P \leq 0.05$.

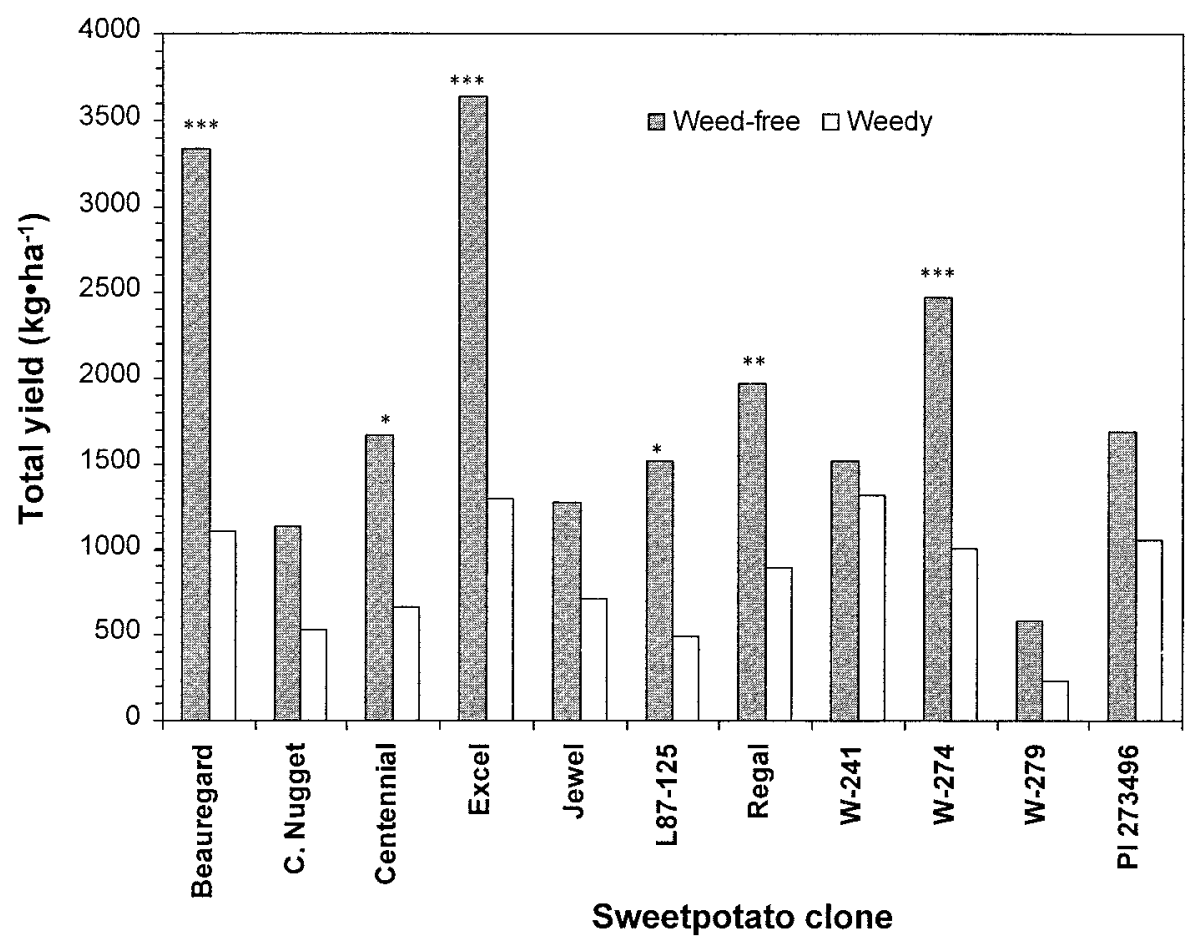

Fig. 1. Yield of sweetpotato clones in weed-free vs. weedy treatments pooled over years and locations. Significant differences between treatment means within a clone at $P \leq 0.05,0.01$, or 0.001 are denoted by $* * *, * * *$, respectively. All other differences between treatments are nonsignificant.

that were present in this study. Allelopathy, the particular weed species present, and weed population distribution represent several confounding factors that make it difficult to identify canopy characteristics that are important in suppressing heterogeneous populations of weeds. In addition, researchers have indicated that the sweetpotato canopy as a photosynthate "source" is less important than the root zone "sink" in determining sweetpotato yield (Kuo and Chen, 1992). A clone with a strong "sink" characteristic may be more tolerant of a reduced canopy or greater competition than is a clone with a weak "sink".

Our data suggest that yield appears to be a useful indicator of weed tolerance. We identified 'Carolina Nugget', 'Jewel', W-241, W279, and PI 273496 as weed-tolerant clones, i.e., clones least affected by weed interference as measured by percent yield reduction by weeds. Three of these five tolerant clones, W241, W-279, and PI 273496, are bunch or medium-internode types, indirectly implicating these plant characters as factors that may minimize yield reductions. Long internode, non-bunch 'Jewel' and 'Carolina Nugget', however, performed as well as did those clones with bunch architecture. In addition, our results show that high-yielding clones in weedfree treatments were the least tolerant to weed interference on a percent reduction basis. However, yields of these clones were comparable with those of the other clones in weedy treatments. The clone 'Beauregard', in particular, is notable as a poor competitor, based on grower experience in the United States and its superior yield performance in absence of weed pressure. Generalizing that high-yielding sweetpotato clones are inferior, on a percent reduction basis, to lower-yielding clones in the current study is premature. Kawano et al. (1974) found high-yielding rice varieties were more competitive than low-yielding ones at wide-row spacings and low $\mathrm{N}$ and conversely so at high planting densities and high N. Further studies with high-yielding sweetpotato clones under different cultural practices are warranted. Split-plot yield comparisons like those used in this study may help breeders identify clones that are able to tolerate weed interference. Similarly, growers can be alerted to clones that yield less under high weed pressure.

Our results have practical implications for sweetpotato breeders in that no particular canopy architecture or characteristic appears significant enough to preferentially select for in a breeding program to suppress weeds in general. One caveat is that canopy architecture may have greater value in a tropical subsistence production system, e.g., densely planted bunch clones in low-N soils, than in our highinput monoculture crop system. Further research in this area appears warranted as well as evaluating competitive ability and tolerance to individual weed species or classes of weeds, e.g., broadleaved weeds vs. grasses.

\section{Literature Cited}

Akobundu, I.O. 1980. Weed science research at the International Institute of Tropical Agriculture and research needs in Africa. Weed Sci. 28:439444.

Akobundu, I.O. 1990. The role of weed control in integrated pest management for tropical root and tuber crops, p. 23-29. In: S.K. Hahn and F.E. Caveness (eds.). Integrated pest management for tropical root and tuber crops. Intl. Inst. Trop. Agr., Ibadan, Nigeria.

Ampong-Nyarko, K. 1994. Weed management in tropical roots and tubers: Yams, cocoyam, cassava and sweetpotato, p. 301-308. In: R. Labrada, J.C. Caseley, and C. Parker (eds.). Weed management for developing countries. Food and Agr. Organization Plant Protection Bul. 120. Rome.

Board, J.E. and Qiang Tan. 1995. Assimilatory capacity effects on soybean yield components and pod number. Crop Sci. 35:846-851.

Boudreaux, J.E. 1994. Commercial vegetable production recommendations. Louisiana Coop. Ext. Serv. Publ. 2433.

Burnside, O.C. 1972. Tolerance of soybean cultivars to weed competition and herbicides. Weed Sci. 20:294-297.

Callaway, M.B. 1992. A compendium of crop varietal tolerance to weeds. Amer. J. Alt. Agr. 7:169-180.

Chandler, J.M. and W.R. Meredith. 1983. Yields of three cotton (Gossypium hirsutum) cultivars as influenced by spurred anoda (Anoda cristata) competition. Weed Sci. 31:303-307.

Ford, G.T. and J. Mt. Pleasant. 1994. Competitive abilities of six corn (Zea mays L.) hybrids with four weed control practices. Weed Technol. 8:124-128.

Harrison, H.F. and J.K. Peterson. 1991. Evidence that sweetpotato (I. batatas) is allelopathic to yellow nutsedge (Cyperus esculentus). Weed Sci. 39:308-312.

Huaman, Z. 1987. Descriptors for the characterization and evaluation of sweet potato genetic resources, p. 331-355. In: P. Gregory (ed.). Exploration, maintenance, and utilization of sweet potato genetic resources. Rpt. First Sweet Potato Planning Conf. Intl. Potato Ctr., Lima, Peru. 
Kawano, K., H. Gonzalez, and M. Lucena. 1974. Intraspecific competition, competition with weeds, and spacing response in rice. Crop Sci. 14:841-845.

Kuo, G. and H.-M. Chen. 1992. Source-sink relationships of sweetpotato, p. 282-295. In: W.A. Hill, C.K. Bonsi, and P.A. Loretan (eds.). Sweetpotato technology for the 21 st century. Tuskegee Univ., Tuskegee, Ala.

Levett, M.P. 1992. Effects of various hand-weeding programmes on yield and components of yield of sweetpotato (Ipomoea batatas) grown in the tropical lowlands of Papua New Guinea. J. Agr. Sci. 118:63-70.

McWhorter, C.G. and E.E. Hartwig. 1972. Competition of Johnsongrass and cocklebur with six soybean varieties. Weed Sci. 20:56-59.

Nelson, D.C. and J.F. Giles. 1989. Weed management in two potato (Solanum tuberosum) cultivars using tillage and pendimethalin. Weed Sci. 37:228-232.

Newcomer, D.T., L.J. Giraudo, and P.A. Banks. 1986. Soybean (Glycine max) cultivar as a factor of weed control in no-till double-cropped pro- duction following wheat (Triticum aestivum) Georgia Agr. Expt. Sta. Res. Rpt. No. 508:16.

Porter, W. 1990. Clomazone for weed control in sweet potato (Ipomoea batatas). Weed Technol. 4:648-651.

Porter, W. 1995. Response of sweetpotato cultivars to metolachlor. HortScience 30:441.

SAS Institute. 1987. SAS/STAT guide for personal computers, ver. 6. SAS Institute, Cary, N.C.

Sweet, R.D., C.P. Yip, and J.B. Sieczka. 1974. Crop varieties: Can they suppress weeds? New York's Food and Life Sci. 7:3-5. 